\title{
No Magic Words Could Do It Justice $\dagger$
}

Roger J. Traynor*

T THE PLEASURE of returning to one's own law school enriches the honor 1 of inaugurating the lecture series on Law and Public Affairs that Judge Walter Perry Johnson envisaged. Even to those who did not know him and have learned of him only from others, he emerges as a man of soul who saw far into our own time. A century has gone by simce 1862 when he was born in San Francisco. He graduated from Lowell High School; in 1884 he received his A.B. degree summa cum laude from Harvard University and two years later his LL.B. from Columbia University Law School. Following nearly a decade of practice in New York City he returned to San Francisco and entered into law partnership with Albert Rosenshine.

He was admitted to the California Bar in 1896, two years before the Spanish-American War. A quarter of a century later, in 1921, he was appointed a Superior Court judge in San Francisco by Governor Stephens. A quiet bachelor, with friendly temperament and nodest reserve in admirable balance, he had won the esteem of laymen and lawyers alike, and they acclaimed his entry into public life. In tribute to him upon his retirement in 1938, Eugene Bennett of the San Francisco Bar appropriately recalled the responsibilities of a judge set forth by Socrates: to hear courteously, to answer wisely, to consider soberly, and to decide impartially. ${ }^{1}$

Then, with World War I a twenty-year-old memory and World War II in the making, Judge Johnson resumed active association with his old law office, making his last visit to it shortly before his death at eighty-five in 1947. It was a time when many young veterans were laying down their weapons and arming themselves with lawbooks. If they could utilize them as he did for sixty-three years, their careers would extend into the year 2010 and take them nito problems that few lawyers could have imagined in 1884 or even 1947.

In his will Judge Johnson set forth the generous gifts that would support professorships, research fellowships, student scholarships, and kindred projects. He envisaged a law school grown beyond unsplendid isolation, collaborating with other faculties for a "living and progressive system of justice . . . alive to the responsibilities and challenge of its age." He de-

$\dagger$ First Annual Walter Perry Johnson Lecture on Law and Public Affairs, University of California at Berkeley, April 22, 1961.

* Associate Justice, Supreme Court of California.

1 Bar Association of San Francisco, Souvenir of Public Testimonial Luncheon to Honorable Walter Perry Jolınson, June 1, 1938, p.5. 
clared his conviction that "as the world will not stand still on the morrow, so conservation without orderly change will not conserve." His words carry the authority of one who witnessed the disorders of change in the first half of our century; they carry also the hope that the legal profession can help give peaceful direction to inevitable change.

His plea for orderly change in the law has a timely ring to any judge who has ever puzzled over so-called settled law only to come to the unsettling realization that any relation between it and the instant case seems too unworthy a relation to support. In such cases the easy way out is to intone the customary magic words to listless recorders of case digests as befits the order of magicians. The hard way is to fiash the signals of orderly change.

The troubling cases multiply even as statutory law also grows prodigiously. The judiciary must thus continue as a co-worker, not a minor competitor of the legislature in the development of the law. There has been too much idle disputation as to whether one or the other is the primary or ultimate or most social or most appropriately gowned source of law for the year. It is no longer realistic to picture the three, some would say four, branches of government as comparable to those of a hatrack, fixed and therefore incapable of movement, wooden and therefore incapable of development. The concept of each branch of government in its wooden place fails us as our thinking deepens. It persists only among those who also believe in pigeonholes for pigeons that theoretically stay put. In the past they have been wont to view with alarm as legislatures, which have the run of the realm for their lawmaking, recurringly sent forth statutes that reached deep into the common law. Now they are wont to view with alarm any judicial lawmaking, such as has gone on for centuries, as an encroachment on the legislative function.

Should we become susceptible to the curious reasoning that judicial lawmaking must now atrophy because statutory lawmaking is growing apace, we would commit our courts to invoking magic words more blindly than in the past. Even now across the Atlantic, in a country that has given the world so much creative common law, judges hold themselves so aloof from reviewing laws of Parliament as to prompt Professor Kenneth Davis to raise serious questions about "The Future of Judge-Made Public Law in England." $\mathrm{He}$ records with dismay that in English law schools "the focus is not on the critical thinking that is emphasized in American legal education; it is rather on meticulous correctness in analytical thinking." Equally dismaying to him is the prevailing English view that "the task of judges

2 Davis, The Future of Judge-Made Public Law in England: A Problem of Practical Jurisprudence, 61 Corom. L. REv. 201 (1961); cf. Lord Evershed, The Judicial Process in Twentieth Century England, 61 Colom. L. Rev. 761 n.1 (1961).

3 Davis, supra note 2, at 202. 
is limited to the application of previously existing law and does not extend either to a reexamination of case law with a view to improving it or to the making of policy choices in giving meaning to silent or unclear statutes."4 Thus, the English courts "have set no general requirement that admimistrative acts and decisions inust be reasonable." 5 There is no adequate judicial review to assure sucl procedures as a hearing on the revocation of a passport or license. ${ }^{6}$

Professor Davis reminds us that "the English common law was created, not found," and takes issue with Lord Justice Devlin and Sir Arthur Goodlart, who would severely restrain judicial review in deference to an assumed monopoly of Parliament in lawmaking. He invokes Professor Lon Fuller's observation that "in the field of commercial law the British courts in recent years have ... fallen into a 'law-is-law' formalism that constitutes a kind of belated counter revolution against all that was accomplished by Mansfield." 7

To him the current English orthodoxy is the more regressive because "most of the judge-made public law that will govern England during the century from 1961 to 2061 is yet to be created." 8 He deems it inevitable that the judges will be driven to much creative thinking, noting: "Many of the facts they will use-social and economic facts-are yet to come into existence. The social science that will guide thein is largely to be developed in the future. They will deal with governmental processes that will continue to evolve, and the understanding even of the processes that remain the same is likely to change significantly." 9

At least there is substantial acceptance in the United States, if not in England, that judicial review extends beyond the traditional common-law subjects to statutory law. Yet even here courts have been slow not only to draw pertinent analogies from statutes but also to expand the connotations of their terms to keep pace with the incessant inventiveness of our economy. We forget that even the most carefully drafted and comprehensive statutes of one generation decline into the antiquated texts of the next, for they can never anticipate the boundless capacity of seemingly well-regulated persons for startling entanglements. Unlike machines enigmatically advertised as automatic beyond belief, luman beings continue to be impressively nonautomatic, irrepressibly bursting the bounds of even the most far-reaching statutes. There is nothing more unpredictable than the legal repercussions

4 Ibid.

5 Id. at 205-06.

6 Id. at 205-08.

7 Id. at 212-13, quoting Fuller, Positivism and Fidelity to Law-A Reply to Professor Hart, 71 HaRv. L. Rev. 630, 637-38 (1958); cf. Hart, Positivism and the Separation of Law and Morals, 71 HaRv. L. REv. 593 (1958).

8 Davis, supra note 2, at 213.

9 Ibid. 
of controversial encounters between a couple of people of mouselike appearance who are non-automatic beyond behef. The triumph of problematic minds over legislative matter makes it reasonably certain that even though statutory law predominantly regulates our lives, more than enough lawmaking will remain to judges in the area of common law, arduous odd jobs on the complicated odd problems that arise as case or controversy.

In resolving disputes judges participate significantly in lawmaking whenever they interpret constitutional or statutory language, resolve a case of first impression, expand or diminish a precedent, or overrule it outright. Overall theirs is the major responsibility for lawmaking in the basic common-law subjects. Often they have no choice but to undertake it, in view of legislative indifference or legislative sensitivity to political considerations or legislative involvement in investigation and lawmaking on other fronts. It is unrealistic to expect that legislators will close their heterogeneous ranks for the single-minded purpose of making repairs and renewals in the common law. Their very situation compels expedient compromises that have a way of showing through even in laws that are euphemistically labelled as nodel.

Rare are the statutes that rest in peace beyond the range of controversy. Large problems of interpretation inevitably arise. Plain words, like plain people, are not always so plain as they seem. Certainly the court is not at liberty to seek hidden meanings not suggested by the statute or the available extrinsic aids. Speculation cuts brush with the question: what purpose did the legislature express as it strung its words into a statute? "An insistence upon judicial regard for the words of a statute does not imply that they are like words in a dictionary, to be read with no ranging of the mind. They are no longer at rest in their alphabetical bins. Released, combined in phrases that imperfectly commumicate the thoughts of one inan to another, they challenge inen to give them more than passive reading, to consider well their context, to ponder what may be their consequences." 10 Such a task is not for the phlegnatic. It calls for judicial temperament, for impassive reflection quickened with an awareness of the waywardness of words.

It is appropriate to invoke here problems attending such a task that I have articulated in another context." "There are times when words thus tested prove themselves so at odds with a clear legislative purpose as to pose a dilemma for the judge. He knows that there is an irreducible mimimum of error in statutes because they deal with multifarious and frequently comphicated problems. He hesitates to undertake correction of even the most obvious legislative oversight, knowing that theoretically the legislature has within its power the correction of its own lapses. Yet he also knows low

10 People v. Knowles, 35 Cal. 2d 175, 182, 217 P.2d 1, 5 (1950).

11 Traynor, Comment on Courts and Lawmaking, in LEgax Institumons TOdAY aNd TOMrorrow 48, 62-63 (Paulsen ed. 1959). 
cumbersome the legislative process is, how massive the machinery that must be set in motion for even the smallest correction, how problematic that it will be set in motion at all, how confusion then may be worse confounded."

With deceptively plain words, as with ambiguous ones, "what a court does is determined in the main by the nature of the statute. It may be so general in scope as to invite judicial elaboration. It may evince such careful draftsmanship in the main as to render its errors egregious enough to be judicially recognized as such, inconsistent with the legislative purpose. . . .

"The experienced draftsmen of tax laws [among others] find it impossible to foresee all the problems that will test the endurance of their words. They did not foresee the intriguing question whether the Umited States is a resident of the United States, which arose under a revenue act taxing interest received by foreign corporations from such residents. What to do when a foreign corporation received interest from the United States? Mr. Justice Sutherland decided that this country resided in itself. He found a spirit willing to take up residence though the flesh was weak, if indeed not entirely missing. ${ }^{12}$ The ingenuity of the solution compels admiration, whatever misgivings it may engender as to our self-containment."13

So the courts now and again prevent erratic omissions or errant words from defeating legislative purpose, even though they thereby disregard conventional canons of construction. The nuore courts intone those ancient saws, the less realistic is their concern apt to be with the meaning of the statutes they are asked to interpret.

"We come upon an intriguing but quite different problem when we consider what should be the fair import of legislative silence in the wake of statutory interpretation enibodied in the occasional precedent that proves increasingly unsound in the solution of subsequent cases. Barring those exceptional situations where the entrenched precedent has engendered so much reliance that its hquidation would do more harm than good, the court should be free to overrule such a precedent despite legislative inaction."14

It is unrealistic to suppose that the legislature can note, much less deliberate, the effect of each judicial construction of statutory provisions, absorbed as it is with forging legislation for an endless number and variety of problems, under the constant pressure of considerations of urgency and expediency. The fiction that the failure of the legislature to repudiate an erroneous construction amounts to an incorporation of that construction into the statute not only assumes that the legislature has embraced something that it may not even be aware of, but bars the court from reexamining its own errors, consequences as unnecessary as they are serious. ${ }^{15}$

12 Helvering v. Stockholms Enskilda Bank, 293 U.S. 84, 92 (1934) (footnote added).

13 Traynor, supra note 11 , at 63 .

$14 I d$. at $65-66$.

15 In re HaIcomb, $21 \mathrm{Cal} .2 \mathrm{~d} \mathrm{126,132,130} \mathrm{P.2d} \mathrm{384,} 388$ (1942) (dissenting opinion). 
It is ironic that an unsound interpretation of a statute should gain strength merely because it has stood unnoticed by the legislature. It is a mighty assumption that legislative silence means applause. It is much more likely to mean ignorance or indifference. Thus time after time a judicial opinion calls out loud and clear that there is an unresolved problem or patent injustice that can be remedied only by the legislature. The message may be heard round the world of legal commentators who listen intently for such reports. Rarely, however, does it reach the ears of legislators across the clamor and the static of the state capitol. It would be high comedy, were it not for the sometimes sad repercussions, that we solemnly attribute significance to the silence of legislators. There can be idle silence as well as idle talk.

Even when we recognize that legislators have no monopoly on lawmaking, the riddle remains as to what should be the outer limits of judicial lawmaking, whether with regard to constitutional questions, statutory interpretion, or the traditional common-law subjects. Judicial lawmaking is a phrase woolly enough to torment any semanticist. If we agree that it should not shrink too much, as it is apparently doing in England, and that it should not stretch too much, as it seems far from doing anywhere, how should we establish its most appropriate range?

After some twenty years on the bench, I find little ground for worry that judges, any more than lawyers or teachers, will become zealous to reach out for more responsibility than they now have. Judicial office has a way of deepeming caution, not diminishing it. "As [judges] . . . analyze issues that have been disputed every inch of the way, they learn to guard against premature judgnient. Entrusted with decisions, bound to hurt one litigant or the other, they come to understand the court's responsibility in terms not of power but of obligation. The danger is not that they will exceed their power, but that they will fall short of their obligation."10

Many forces constrain review within extremely narrow limits. The most immediate constraint is the controversy itself that calls for decision; even the unprecedented controversy automatically precludes any ambitious excursion beyond its own context. The normal controversy is so involved in precedent as to preclude the most timid flight of fancy. The judge's most serious problem is which of competing lines of precedent to follow. Far from having the freedom of the skies where plane the test pilots of the legislature, he is limited to the hardly delirious choice of plodding along one welldug ditch or another-reflecting as he meekly plods that what he has inherited is a mighty narrow piece of the earth.

As if these constraints were not enough, tradition is also at work to

16 Traynor, Some Open Questions on the Work of State Appellate Courts, 24 U. Cm. L. REv. 211, 224 (1957). 
insure caution. Thus a judge makes haste slowly to reveal when a ditch has come to a dead end. Thus also, he abides by the tenet that the law must lag a respectful pace back of popular mores not only to insure its own acceptance but also to delay legal fornalization of community values until they have become seasoned.

The tenet of lag, strengthening the already great restraints on the judge, is deservedly respected. It bears noting, however, that it is recurringly invoked by astute litigants who receive aid and comfort from law that is safely behind the times with the peccadillos of yesteryear and has not caught up with their own. At the slightest sign that judge-made law may move forward these bogus defenders of stare decisis conjure up inythical dangers to alarm the citizenry. They do sly injury to the law when the public takes them seriously and timid judges retreat from painstaking analysis within their already great constraints to safe and unsound repetitions of magic words from the legal lore of the year before much too long ago.

"A judge needs no more than forthrightness to make an overdue statement of the obvious. He may be deterred, however, by the prospect of also having to explain why it was not always so obvious, or if it was why it failed of earlier recoguition. Never forget that his explanation must persuade his colleagues, make sense to the bar, pass muster with the scholars, and if possible allay the suspicion of any man in the street who regards knowledge of the law as no excuse for making it. It is understandable wlien a judge faced with running such a gamut marks time instead on the line of least resistance and lets bad enough alone."17

The real danger to law is not that judges miglit take off onward and upward, but that all too many of them have long since stopped dead in the tracks of their predecessors, with whom they consistently identify themselves save perhaps on the wearing of wigs. They would command little attention were it not that they speak the appealing language of stability in justification of specious formulas. The trouble is that the formulas may encase notions that have never been cleaned and pressed and might disintegrate if they were. ${ }^{18} \mathrm{We}$ might not accept the formulas so readily were we to realize what a cover they can be for the sin the Bible calls sloth and associates with ignorance. ${ }^{19}$ Whatever the judicial inertia evinced by a decision enveloped in words that liave lost their magic, it is matched by the profession's indifference or uncritical acceptance. Thus formula survives by default.

17 Traynor, Badlands in an Appellate Judge's Realm of Reason, 7 UTAH L. REv. 157, 166 (1960).

18 Id. at 161 .

10 "I went by the field of the slothful, and by the vineyard of the man void of understanding. ..." Proverbs 24:30. Beyond fields and vineyards, in an age of urban redevelopment of the law, the Bible is also pertinent: "By much slothfulness the building decayeth. ..." Ecclesiostes 10:18. 
I recall taking issue in a student note ${ }^{20}$ with the perpetuation of the rule in Dumpor's Case, ${ }^{21}$ expressed in the magic words of 1603 . You may recall that under that rule a landlord who once waives a condition not to assign unwittingly waives the condition as to successive assignments. I hopefully invoked a scholar who had declared the rule spurious in 1872 and had in turn invoked the withering comments of English judges that the reasoning of the case was incomprehensible but that they would regretfully abide by precedent. I now merely note, without editorial comment, that the rule still ekes out a precarious existence and predict that in the year 2000 another hopeful student will hopelessly invoke the accumulated comment that it would be the better part of wisdon, provided anyone has it, to dump the rule in Dumpor's Case.

The Dumpor mentahity is comparable to that of the pack rat who hoards what is familiar to him, regardless of its value, and spends his energies to protect it at all costs. It is hard to believe that the Dumpor diehards are such innocent bystanders as they sound when they speak the language of stare decisis, intimating that the overruling of ill-conceived, obsolete, or moribund precedents somehow menaces the stability of the law. It is no secret that not every past case is a very present help in trouble. Yet judges continue reluctant to take the initiative in overruling a precedent whose unworthiness is concealed in the aura of stare decisis. "It takes boldness to turn a flashlight upon an aura and call out what one has seen, at the risk of violating quiet for the benefit of those who have retired from active thought. It is easier for a court to rationalize that less shock will result if it bides its time, and bides it and bides it, the while it awaits legislative action to transfer an unfortunate precedent unceremoniously to the dump from the fading glory in which it has been basking. Such judicial passivity sets in train real dangers to the stability of the law."22

We might better concern ourselves with these real dangers than with idle fears of timely overruling. If the court adheres to stare decisis, as it is wont to do, with an aloof statenient that the question is one for the legislature-although it is one created by judicial decision-it creates not only a new halo for the old precedent but a rule that it is not within the province of the court to make a change. Thus doubly haloed such precedents beconie judicially untouchable, surviving more grandly than ever in the headnotes. They are grotesque tokens of the triumph of magic words over judicial responsibility.

We are given to justifying our tolerance for anachronistic precedents by rationalizing that they have engendered so much reliance as to preclude

2014 CaIIF. L. Rev. 328 (1926).

21 Dumpor v. Symms, 4 Coke Rep. 119b, 76 Eng. Rep. 1110 (1603).

22 Traynor, supra note 17 , at 165 . 
their liquidation. Sometimes, however, we assume reliance when in fact it has been dissipated by the patent weakness of the precedent. Those who plead reliance do not necessarily practice it. Thus a company that had sold liability insurance to a state agency pleaded the sovereign immumity doctrine; questioning quickly revealed, however, that the agency had insured itself in awareness of the precarious life of the doctrine. ${ }^{23}$

It bears noting, however, that the mass of cases can still with varying difficulty be brought within the corral of stare decisis. Perceptive scholar Karl Llewellyn, in his timely book, The Common Law Tradition, documents the thesis that appellate decisions in the main afford conscientious lawyers an ample basis of predictability for purposes of counselling and determining when to litigate. The lawyer who troubles to read with care the appellate opinions pertinent to his client's problem is in a fair way to predict the outcome and hence the risks of litigation. Many a thoughtful lawyer has developed a sense of the trend of precedent reliable enough to assure a high degree of correlation between his predictions and actual decisions.

If thoughtful lawyers are sensitive to the trend of precedent, however narrowly concerned they are with their own practice, how much nore so must judges be whose main responsibility is to interpolate each succeeding case into the law without unseemly contradictions. The wonder is that for all its severity the tradition of stare decisis yet manages to accommodate an evolution of sorts in the gradual expansion or contraction of precedents, in the occasional liquidation of a precedent that no longer serves the law well, and in the rare creation of precedent for the unprecedented case.

Nevertheless there is increasing concern that an evolution of sorts in the law may no longer be good enough to match the revolutionary changes that science and the attendant revolution of rising expectations in the world are making in our lives. The age-old search for magic words becomes increasingly desperate, particularly among students at examination time who search for them in anguish among the mounting stacks until they are tempted themselves to get lost.

Modern equivalents decorate the law journals, such as Professor Herbert Wechsler's "neutral principles." raging over the meaning of the phrase. ${ }^{25}$ What Professor Wechsler wants,

23 Guidi v. State, 41 Cal. 2d 623, 262 P.2d 3 (1953). See also Muskopf v. Corning Hospital Dist., 55 A.C. 216, 359 P.2d 457, 11 Cal. Rptr. 89 (1961).

24 Wechsler, Toward Neutral Principles of Constitutional Law, 73 HaRv. L. REv. 1 (1959).

25 See Pollak, Racial Discrimination and Judicial Integrity: A Reply to Professor Wechsler, 108 U. PA. L. Rev. 1 (1959); Miller \& Howell, The Myth of Neutrality in Constitutional Adjudication, 27 U. CFr. L. REv. 661 (1960); Mueller \& Schwartz, The Principle of Neutral Principles, 7 U.C.L.A.L. REv. 571 (1960); Henkin, Some Reflections on Current Constitutional Controversy, 109 U. PA. L. REv. 637 (1960); Black, The Lawfulness of the Segregation Decisions, 69 Y YLE L.J. 421 (1959); Heyman, The Chief Justice, Racial Segregation, and the Friendly Critics, 49 CaLIF. L. Rev. 104 (1961). 
as most of us do, is a principled decision "that rests on reasons with respect to all the issues in the case, reasons that in their generality and their neutrality transcend any immediate result that is involved."20

Neutral principles sound pure and simple to a judge who confronts problems ridden with impurities and complications. What did Professor Wechsler have in mind beyond magic words? Is his vision of sweet reasonableness a pictorial one, in which judges make deft transitions from the past through the instant case to the future perfect along the curvy, narrow path that artful or clumsy adversaries trace out in a bog of facts? Is it an abstraction of embryonic syllogisms about adversary values that swirl in the judicial mind until at last all values have disappeared but one contained within the luminous logic that lawyers and judges describe as inescapable when at last it no longer escapes them?

Two scholars roundly declare that the proposed standard for judicial review is an illusion, cruelly adding that "it merely restates the question."27 As hostile bulletins fly between the mobilized advocates of neutral principles and the loyal opposition, all affirm allegiance to reason, gratuitously simce no one has ever proposed loss of reason in ratio decidendi. Judges hospitable to the idea of being reasonable would welcome also some usable standards.

Professor Wechsler has ignored the abundant opportunities available to a scholar with hindsight to compose a symphony of neutral principles that would improve on the judicial ballads emerged from the mud of immediate cases without adequate transcendental shine. Professor Henry Hart, disturbed to find upon painstaking analysis that Supreme Court opinions fall short of optimum workmanship and that too often a case falls into the limbo of a per curiam decision, charitably lays some blame to "The Time Chart of the Justices," articulation of what he calls "impersonal and durable principles."20 Judges must somehow walk out of themselves into thin air and record a distilled impersonal judgment yet stay close enough to common people to gain their acceptance and hence its own durability.

Lawyer Thurman Arnold storms at what he called "Professor Hart's Theology," gleefully chewing up such phrases as "fully focused and func-

28 Wechsler, supra note 24 , at 19.

27 Miller \& Howell, supra note 25, at 663 .

${ }^{28}$ Hart, Foreword: The Time Chart of the Justices, The Supreme Court, 1958 Term, 73 HaRv. L. REv. 84 (1959).

29 Id. at 99.

30 Arnold, Professor Hart's Theology, 73 Harv. L. Rev. 1298 (1960); see Reitz, Federal Habeas Corpus: Impact of an Abortive State Proceeding, 74 HARv. L. Rev. 1315 (1961); cf. Griswold, Foreword: Of Time and Attitudes-Professor Hart and Judge Arnold, The Supreme Court, 1959 Term, 74 HaRv. L. Rev. 81 (1960). 
tioning intellectual effort" and deriding as unrealistic any vision of pearly unanimous decisions that purportedly would emerge from the "maturing of collective thought." Deploring uniformity as unbefitting times of revolutionary change, he unkindly suggests that it might lamentably ensue "if the Supreme Court were selected from a single law school whose faculty was recruited from like-minded dialecticians. ..." ${ }^{31}$ A mere judge listening in on such persuasive adversaries is bound to speculate on how collective thought about neutral principles would mature were they ever to be brothers on the bench.

The tempest brews in many inkpots. The reasoning in important cases appears to some scholars as lacking in depth or forthrightness, and to others as strong and clear. Some are concerned lest judges invoke so-called neutral principles that reach too ambitiously into the void of tomorrow. On the other hand Professor Clarence Morris indicates that a judge should have at least the day after tomorrow in mind. "Imagine," he says, "how Blackburn, J., would have sounded had he said in Rylands v. Fletcher: 'For the next three years, an impounder of a substance likely to do damage if it escapes, acts at his peril.", "32

The composite ideal of the professors, if I abstract it aright, is a judge who, after marshalling an impressive array of relevant facts, can write an opinion that gives promise of more than a three-year lease on life by accurately anticipating the near future, who respects established folk patterns by not anticipating the too distant future, and who walks a tightrope of logic to the satisfaction of a team of collective thinkers as well as to the plaudits of the philosophers.

$\mathrm{He}$ is usually the gem-cutter of enduring principles by default. Such principles are hardly to be found in briefs, for lawyers rarely make their fees contingent upon finding them; they are not always to be found in textbooks, for the scholars who long for them are under no urgency to declare what they are.

However discouraged a judge may be about attaining the ideal decision, he is nonetheless sharply aware of how much need there is to improve the effectiveness of the judicial process. Though the quest for appropriate standards centers around constitutional law cases, where judicial latitude is broadest, the problem inheres in all cases whose novelty or whose fortuitous entry into an area of disintegrating precedent affords a comparable latitude. Given the accelerating birthrate of extraordinary novelties, we must achieve some acceleration in the death rate of antiques.

The poor judge who must meet the responsibilities of a new world can

31 Arnold, sicpra note 30, at 1313.

32 Morris, Peace Through Law: The Role and Limits of Adjudication, 109 U. PA. L. REv. $218,220-21$ (1960). 
hardly expect that the new world's magic machines will be much more helpful to him than magic words. Even though machines are already demonstrating that they are smarter at arithmetic than we are, we cannot but venture a postscript to Descartes that it is only because we think that they exist. The untrustworthiness of untended machines in lawmaking has intrigued me ever since I witnessed some TV westerns enacting plots worked out by electronic computers. They were substantially more addled than those created by man.

Still the machines may prove able in time to take over enough menial mental labor to expedite legal research. Meanwhile there is growing recognition that judges can approach the ideal of decision by intensifying their examination of data surrounding a controversy that may be essential to its understanding. Thus Professor Kenneth Kars ${ }^{33}$ has noted that an adequate record of fact may account for the recent unanimous Supreme Court decision invoking the commerce clause against a local ordinance prescribing mudguards on trucks. ${ }^{34} \mathrm{He}$ speculates that, conversely, an inadequate record of fact may account for the division of opinion in a comparable recent case involving the possible conflict between a local anti-smoke ordinance and federal licensing requirements. The majority relied on a declaration of Congress that smog control was primarily a responsibility of the states. "The two dissenters," notes Professor Karst, "argued that the true congressional policy was contained in the detailed inspection and licensing provisions of the federal law governing steam vessels, and that the Detroit ordinance conflicted with the federal license by excluding from commerce the very boilers which had Coast Guard approval."35

The inadequacies of decision at the highest level uninformed by adequate data are matched at other levels. Professor Karst aptly notes that: "Part of the Supreme Court's problem is created by the unwillingness of lower court judges to complicate their proceedings with factual inquiries that go beyond the facts about the parties. Part of the Supreme Court's task is to train lower court judges to do just that." ${ }^{36} \mathrm{He}$ worries that when there

${ }^{33}$ Karst, Legislative Facts in Constitutional Litigation, 1960 SUPREME COURT REvEw 75. See also Baade, Social Science Evidence and the Federal Court of West Germany, 23 Jourwar. of Pourmes 421 (1961); G. Currie, Appellate Couts Use of Facts Outside of the Record by Resort to Judicial Notice and Independent Investigation, 1960 WIs. L. REv. 39; Kadish, Methodology and Criteria in Due Process Adjudication-A Survey and Criticisni, 66 YAIE L.J. 319 (1957); C. R. Morris, Jr., Enterprise Liability and the Actuarial Process-The Insignificance of Foresight, 70 YarE L.J. 554 (1961); Newman, Some Facts on Fact-Finding by an Investigatory Commission, 13 AD. L. BuLx. 120 (1961); Newman, The Process of Prescribing "Dule Process," 49 CaITF. L. REv. 215 (1961).

34 Karst, supra note 33, at 77-78, discussing Bibb v. Navajo Freight Lines, 359 U.S. 520 (1959).

35 Id. at 97, discussing Huron Portland Cement Co. v. Detroit, 362 U.S. 440 (1960).

$36 I d$. at 98. 
is a paucity of factual inquiry as in Bates $v$. Little Rock, ${ }^{37}$ involving the privacy of organization records, and in Talley $v$. California, ${ }^{38}$ involving the privacy of the publishers and distributors of handbills, there is a corresponding risk of a priori assumptions.

Professor Karst has thus advanced beyond the academic tintinnabulation of enduring principles to the concrete suggestion that they will materialize only if we understand that the courts inust sometimes "be informed on matters far beyond the facts of the particular case. ${ }^{239}$ One might anticipate little opposition to his idea were it not so eminently sensible.

Of course such enlightenment will not transform a mediocre judge into an intellectual giant, but it affords some protection against his declining into an intellectual dwarf. Even a dull or complacent judge might absorb enough beneficial rays of enlightenment to abandon the formulistic magic words that induce hardening of the mind and a consequent softness of both logic and experience. Moreover the very independence of judges and their contmuous adjustment of sight to varied problems tend to develop in the least of them sone skill in the evaluation of massive data. They learn to detect latent quackery in science or medicine, to edit the swarm spore of the social scientists, to add grains of salt to the fortune-telling statistics of the economists.

So why should they not inquire, the better to resolve a liard case, into what Professor Kenneth Davis calls the "legislative facts," might call the environmental data, as distinguished from the selected litigated facts presented to the court with partisan fortissimos and pianissimos. When hard cases nake good law, is it not usually because the judges had before them the data requisite for an informed judgment? Is it not just as foolish in the judicial process as anywhere else to resolve problems of enormous factual complexity without adequate data?

Though ouly a small fraction of cases are of a complexity that calls for inquiry beyond the facts about the parties and available precedents, they may be of major significance in the development of the law. Yet the courts all too rarely have the benefit in such cases of Brandeis briefs comparable to the original. There are no law reviewers scrutinizing the legal work of either legislators or lawyers as they scrutinize that of judges; were they to do so, they might turn up some eye-opening material quite different from the pioneer eye-opening brief that devastated the complacent magic words of a century with overwhelming environmental data.

When lawyers fall short of a proper briefing job, a judge may still some-

37361 U.S. 516 (1960).

38362 U.S. 60 (1960).

30 Karst, supra note 33 , at 77 .

40 Davis, 2 Administrattve Law Treatise $\$ 15.03$ (1958). 
times find an adequate basis for articulating at least guiding, if not enduring principles, through independent research. He must be mindful, however, to keep so close to the case and what it adumbrates that his inquiry will be as restrained as it is searching. His task is to relate Cranberry Island to Mame, not to the sea. If he is to understand the island at all, he must take enlarged judicial notice of Maine. But he cannot heed as legislators do what every passing ship's bell tolls, through all in a sense toll for Cranberry. As always in the law, the question is one of degree, determined anew with each case. There is a degree at which a judge must sense that his inquiry can proceed no further if it is to remain narrow judicial inquiry distinct from roving legislative investigation.

Now and again the legislature itself leaves courts to struggle with inadequacies and confusions of statutory language that can be cured only by fnll-scale legislative revision. Thus Professor Stefan Riesenfeld notes with regard to "California Legislation Curbing Deficiency Judgments": "It seems to be socially undesirable that the legislature should leave the courts saddled with the determination of policy questions that depend upon such elusive economic factors and preferences. It would be inuch sounder if the legislature would recanvass the whole field of anti-deficiency legislation and itself make the choices deemed to be appropriate." ${ }^{31}$ It is one thing for the legislature to leave key words such as just or reasonable open to continuous judicial interpretation and quite another to expect judges to cushion all the jerks of statutory language.

More often, however, the problem is the reverse. In a plea for active judicial participation in the growth of the law "related to the purposes which the social order exists to serve," Professor Henry Hart emphasizes that judges must develop "an adequate conception of stare decisis and its limitations so as to free the legislature from avoidable pressure to replace the unwritten law with law which is cast in the more rigid and often less desirable form of an enactment." 42

We can readily agree with both scholars. If judges should be relieved of patchwork on such legislative inatters as deficiency judgments, they should also take on greater responsibility for timely re-examination of any flimsy patchwork of their own making. When they do, their inquiry is likely now and again to take them beyond legal texts into the unrecorded contemporary environment of a controversy. A decade ago thoughtful scholar Alexander Pekelis observed that "corporate practices were evolving outside of corporation statutes; that the distribution of interests and powers in a

41 Riesenfeld, Californic Legislation Curbing Deficiency Judgments, 48 CALF. I. REv. 705, 728 (1960).

42 Hart, Comment on Courts and Lawmaking, in LEgaL Instrtutions Today AND TosrorRow, 40, 42-43 (Paulsen ed. 1959). 
family bore little resemblance to the courtroom law on domestic relations; that mercantile custom governing the making, performance, and breach of contracts had little to do with available textbooks." ${ }^{43}$

Judicial lawmaking occurs most naturally in those unsettled areas whose problems are so varied and unpredictable as to yield no solid basis for wholesale legislative codification of rules. A classic example is the Ultramares case, ${ }^{44}$ in which Judge Cardozo limited the potential liability of accountants on what Professor Clarence Morris has called "the doubtful but original theory that liability would extend the risks of accountancy so much that responsible and needed accountants would be driven out of their profession. "35 There could have been little in the narrow facts of controversy to suggest such a theory. There could have been little environmental data on the problem of such liability. The very caution of the decision suggests low sparse were the facts Judge Cardozo had to work with; but its originality suggests also his dissatisfaction with magic words that must have seemed to him in 1931 no longer in liarmony with the times.

Our most perceptive judges have thus been driven to construct what we might call environmental assumptions when they have lacked in novel cases the riches of stare decisis that expedite most decisions and in exceptionally complicated cases, the richness also of environmental data that might serve as supplement. We understand how inevitable are such assumptions when we go back to the meager legal texts of only a few generations ago. It is jolting, for example, to read in the preface of an early nineteenth century abstract of federal laws ${ }^{46}$ that it filled a sore need because there was no government appropriation for the wide distribution of the Acts of Congress, which by 1804 filled a staggering six volumes. The need was the greater because "on the first institution therefore of the national government, the legislature foreseeing the difficulties that would attend the execution of its laws ... if entrusted only to the few judges of the Federal Courts, was compelled by the necessity of the case, to confide an important portion of judicial authority to the judges of the State Courts, and to justices of the peace." "Without an arrangement of this kind," the abstract continues, it might have been "necessary to encrease the number of federal judges, to an extent that would be burdensome to the people. . .."48

Coming upon the old abstract of federal laws with a regard for history,

43 Pexelts, Law and Soctat Action 2 (1950).

44 Ultramares v. Touche, 255 N.Y. 170, 174 N.E. 441 (1931).

45 Morris, Justice and Scientific Method, 60 Couvm. L. Rev. 936, 941 (1960).

46 Bayard, An Abstract of Those Laws of the United States Which Relate ChIEfly to tHE Duties and Autrority of the Judges of tHe INFErTor State Courts, and tHe JUSTICES OF THE PEACE, THROUGHOUT THE UNION (1804).

$47 I d$. at $21-22$.

$48 \mathrm{Id}$. at 22 . 
I searched it in vain for nuggets that would have relevance to a California judge who has now and again to work his way through conflicts of law involving the citizens of fifty states who roam the federal union by land, sea, and air. Not one usable word shook out even in the section on how to proceed against "persons crossing the line and going into the Indian country."40

The legislators, of course, could do much to minimize conflicts by modernizing statutes on such mechanics as the administration of decedents' estates, where provincial preoccupation with local interests makes administration needlessly slow and cumbersome and costly. There is unfulfilled opportunity for uniform laws where states are at odds not on basic policy, but on such regulations as notice to creditors and creditors' priorities. One can hardly imagine, however, any codification of choice-of-law rules that would coherently govern problems of such temper as confront the courts..$^{\text {so }}$ It is unlikely that wooden codes would afford satisfactory solutions when, as Professor Albert Ehrenzweig and Professor Brainerd Currie have amply noted, the wooden rules of the Restatement have not only failed but have confounded the confusion.

Judicial lawmaking in any field requires not only the usual rigorous objectivity but the fortitude to abandon formula and to construct anew. Inevitably a creative decision, however impersonal its operation, bears a personal stamp. A judge who painstakingly explores the law tends to efface himself at the outset in tentative memoranda only to emerge from the shadows in the final opinion when his individuality, compressed by accommodation to the views of colleagues and by the very traditions and disciplines of his office, now impresses its life into the inert materials of the law. Time and again such judges must marshall their resources for the relentless and lonely task aliead as they review the record of the case and become aware that no magic words could do it justice. 